\title{
CARBON STOCKS IN MINED AREA RECLAIMED BY LEGUMINOUS TREES AND SLUDGE ${ }^{1}$
}

Fabiano de Carvalho Balieiro ${ }^{2 *}$,Carolina Araújo Costa ${ }^{3}$, Raphael Braga de Oliveira ${ }^{4}$, Rafaela de Oliveira ${ }^{4}$, Guilherme Kangussu Donagemma², Aluisio Granato de Andrade² and Cláudio Lucas Capeche ${ }^{2}$

${ }^{1}$ Received on 20.09.2016 accepted for publication on 24.11.2017.

2Embrapa Solos, RiodeJaneiro, RJ-Brasil.E-mail:<fabiano.balieiro@embrapa.br>,<guilheme.donagemma@embrapa.br>, <aluisio.granato@embrapa.br> and <claudio.capeche@embrapa.br>.

${ }^{3}$ Universidade Veiga de Almeida,Rio de Janeiro, RJ-Brasil.E-mail:<carolbiorj@gmail.com>

${ }^{4}$ Universidade Federal Rural do Rio de Janeiro,Seropédica, RJ-Brasil.E-mail:<rafaelbraga.agronomia@gmail.com>and <rafaelaforestal@gmail.com>

*Corresponding author.

\begin{abstract}
Few studies have been carried out on aboveground (or belowground) and soil/substrate C accumulation in severely degraded areas, such as mined areas. The present study was developed in order to find a recovery strategy for a mined area and characterize its potential for $\mathrm{C}$ sequestration by planting two nitrogen-fixing Brazilian tree species (Mimosa caesalpiniifolia Benth and M. bimucronata (DC.) O. Kuntze). Sewage sludge was included in the experimental design. An experiment under randomized block condition and $2 \times 5$ factorial design with four replications were defined and carried out, in Rio de Janeiro State, Brazil. The treatments consisted of a combination of both tree species and five sewage sludge doses $\left(0,2.85 ; 5.70 ; 11.40\right.$ and $\left.22.80 \mathrm{Mg} \mathrm{ha}^{-1}\right)$. M. caesalpiniifolia grows better $(\mathrm{p}<0.05)$ in reclaimed areas than $M$. bimucronata, even though neither the height nor the basal area of both species responded to the sludge application. Carbon stock in the tree trunks differ between species (27.3 and $14.3 \mathrm{Mg}^{-} \mathrm{ha}^{-}$ ${ }^{1}$, for $M$. caesalpinifolia and M. bimucronata, respectively), and was influenced by the doses of sewage sludge, whereas the soil carbon stock $\left(0-10 \mathrm{~cm}\right.$ ) did not differ between species and doses (12.0 and $12.2 \mathrm{Mg} \mathrm{ha}^{-1}$, for $M$. caesalpiniifolia and $M$. bimucronata, respectively). Soil fertility in the degraded site was found to be improved by legume trees six years after planting, with a small influence of the sewage sludge level. Mined areas recovered with legume trees can sequestrate significant amounts of $\mathrm{C}$ both in aboveground biomass and soil in a short period of time.
\end{abstract}

Keywords: Soil carbon and nutrients accretion; Reclamation of soil; Aboveground biomass accumulation.

\section{ESTOQUE DE CARBONO EM ÁREAS DE MINERAÇÃO RECUPERADA COM LEGUMINOSAS ARBÓREAS E LODO}

\begin{abstract}
RESUMO - Poucos estudos foram conduzidos em relação à acumulação de C na parte aérea (ou subterrânea) e solo/substrato em áreas severamente degradadas, como áreas mineradas. O presente estudo foi desenvolvido para encontrar uma estratégia de recuperação para uma área minerada e caracterizar o seu potencial de sequestro de C a partir do plantio de duas espécies de árvores brasileiras que fixam nitrogênio do ar (Mimosa caesalpiniifolia Benth e M. bimucronata (DC) O. Kuntze). Lodo de esgoto foi incluído no desenho experimental. Assim, um experimento em delineamento em blocos ao acaso e esquema fatorial 2 × 5 e quatro repetições foi instalado no estado do Rio de Janeiro, Brasil. Os tratamentos consistiram em uma combinação de duas espécies arbóreas e cinco doses de lodo de esgoto $\left(0,2,85 ; 5,70 ; 11,40\right.$ e 22,80 $\left.\mathrm{Mg} \mathrm{ha}^{-1}\right)$. M. caesalpiniifolia cresceu melhor $(p<0,05)$ na área recuperada do que M. bimucronata, mesmo que nem a altura, nem a área basal de ambas as espécies tenham respondido à aplicação do lodo. O estoque de carbono nos troncos das árvores diferiu entre as espécies (27,3 e 14,3 Mg ha ${ }^{-1}$, para M. caesalpinifolia e M. bimucronata, respectivamente) e foi influenciado pelas doses de lodo de esgoto, enquanto o estoque de carbono do solo $(0-10 \mathrm{~cm})$ não diferiu entre espécies e doses (12,0 e 12,2 Mg ha-1, para M. caesalpiniifolia e M. bimucronata, respectivamente). A fertilidade do solo no local degradado foi melhorada pelas leguminosas, seis anos após o plantio, com uma pequena influência do lodo de esgoto. Áreas mineradas recuperadas com leguminosas podem sequestrar quantidades significativas de C, tanto na biomassa aérea quanto no solo em um curto período de tempo.
\end{abstract}

Palavras-Chave: Acréscimo de carbono e nutrientes do solo; Recuperação de solos; Acúmulo de biomassa da parte aérea.

Revista Árvore. 2017;41(6):e410610

http://dx.doi.org/10.1590/1806-90882017000600010 


\section{INTRODUCTION}

In severely degraded lands, such as mining areas, the loss of local "ecological memory” (Bengtsson et al., 2003) may result in high rehabilitation costs, since ecological memory is suggested to hamper the natural development of either simple or complex vegetation communities (Silva et al., 2013). On the other hand, the period after rehabilitation intervention is an important factor for the return of key properties to both degraded soil and vegetation structure (Parrotta and Knowles, 1999; Balieiro et al., 2008; Reis, 2006; Banning et al., 2008; Chaudhuri et al., 2013; Wick et al., 2013). However in some cases restoration of soil quality could occur faster than the vegetation community (Parrotta and Knowles, 1999; Silva et al., 2013). The selection and the number of species to be planted (Parrotta and Knowles, 1999; Rodrigues et al., 2009), the use of organic residues, conditioners (such as biosolid, ash or top soil), lime and/or fertilizers (Fortes, 2000; Bendfeldt et al., 2001; Reis, 2006; Shrestha and Lal, 2006; Wick et al., 2013; Silva et al., 2013) or even the planting method (direct seeding or use of seedlings) are factors that may accelerate biomass accumulation in different compartments of the recovering ecosystem, as well as soil $\mathrm{C}$ sequestration and the return of certain ecological soil functions (Camargo et al., 2002; Parrotta and Knowles, 2001; Reis, 2006; Banning et al., 2008; Kanowski and Catterall, 2010; Evans et al., 2013; Silva et al., 2013).

The use of fast growing $\mathrm{N}_{2}$-fixing legume trees in the rehabilitation of severely degraded lands has been considered an advantage by several researchers (Franco and Faria, 1997; Macedo et al., 2008; Yang et al., 2009; Wang et al., 2010; Chaer et al., 2011). Most of them have reported that the natural introduction of biologically fixed $\mathrm{N}$ can intensify nutrient cycling and stabilize soil organic matter in these environments, and hence improve the quality of the degraded substrate. A significant soil C stock (0-60 cm: $\left.88.1 \mathrm{Mg} \mathrm{ha}^{-1}\right)$ and a high rate $\left(1.73 \mathrm{Mg} \mathrm{ha}^{-1}\right.$ year $\left.^{-1}\right)$ of storage of this element were found after 13 years of a reforestation using $\mathrm{N}_{2}$. fixing legumes (Acacia mangium, A. auriculiformis, Enterolobium contortisilicquum, Gliciridia sepium, Leucena leucocephala, Mimosa caesalpiniifolia and Paraseroanthes falcataria) in a reclaimed area aggravated by gully erosion (Macedo et al., 2008). On the other hand, depending on the quantity and quality of the material deposited on the soil, the benefits may not be as good as expected (Parrotta and Knowles, 1999; Singh et al., 2006; Wang et al., 2010). Parrotta and Knowles (1999) reported that in areas of bauxite mining, while fast growing commercial tree species (Eucalyptus camaldulensis, E. citriodora, E.pellita, E. torreliana, E. urophylla, Acacia mangium and Sclerolobium paniculatum) presented high growth and deposited significant amounts of litter on the substrate, the slow decomposition rate of these residues prevented the development of the organic horizon in bauxite waste tanks. Moreover, the authors mentioned that such recalcitrant organic material affected succession negatively, as the litter layer layer was suggested to physically avoid seed germination. Singh et al. (2006), who studied coal mines in India, Wang et al. (2010), who evaluated areas degraded by erosion in China, and Resende et al. (2006), who monitored reclaimed areas in southeastern Brazil, observed different soil C sequestration rates and soil fertility recovery (nutritional status), depending on the species planted, which corroborates the hypothesis that the species - even among legume trees - can have different effects on soil quality. Evaluating a 14-year restoration chronosequence in an opencast mine area, Silva et al. (2013) attributed soil C accumulation to the synergic effect of these resource inputs and the invasion of an exotic species. Using a multi-proxy approach, combining vegetation survey with the analysis of plant and soil isotopic abundance and chemical and physical fractionation of SOM, these authors observed a consistent increase of soil C:N, C:P and $\Delta^{15} \mathrm{~N}$ over time, reflecting the effects of invasive grasses controlling resource availability.

Few studies have been carried out in Brazil regarding the $\mathrm{C}$ accumulation capacity both in the aboveground and soil/substrate of severely degraded areas. We believed that by increasing tree growth and biomass return to the soil the ecosystems would increase its C sequestration capacity as well as its quality. The present study was developed in order to find a recovery strategy for a reclaimed area and to characterize its potential for $\mathrm{C}$ sequestration by planting two native Brazilian $\mathrm{N}_{2}$-fixing legume tree species, Mimosa caesalpiniifolia Benth and M. bimucronata (DC.) O. Kuntze. Sewage sludge application was included in the experimental design. The hypothesis was that (i) the mined areas could sequester significant quantities of $\mathrm{C}$ both in aboveground biomass and soils, and (ii) the sludge would act as a source of nutrients and a soil conditioner as well, thus accelerating the nutrient

Revista Árvore. 2017;41(6):e410610 
dynamics and the growth of planted species. This study aims to evaluate the growth and aboveground biomass production of two leguminous tree species, cited above, under mining areas and the ability of both species to modify soil fertility and C stocks.

\section{MATERIALAND METHODS}

\subsection{Site description}

The experiment was carried out in an area of the Rio de Janeiro/Galeão-Antonio Carlos Jobim International Airport called “Jazida de Itacolomi”, located at $22^{\circ} 48^{`} 49^{\prime}$ 'S

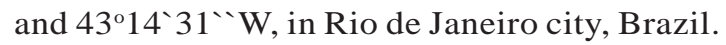

Regarding regional climatic characterization, the study area is located in the intertropical strip, between the mountains and the sea in the Southeast region, with a humid tropical climate characterized by two distinct seasons. According to the Köppen and Geiger climate classification, Rio de Janeiro city has an Am climate, with an average annual rainfall around 1,278 mm. July is the driest month $(\sim 55 \mathrm{~mm})$ and January is the rainiest ( $\sim 149 \mathrm{~mm})$. The annual temperature reaches an average of $23.2^{\circ} \mathrm{C}$. Local land use history has been detailed by Bezerra et al. (2006). In summary, three ha were degraded due to clay extraction for the construction of the second passenger terminal of the airport. Before exploitation, the area was covered with a Yellow latosol (Oxisol), with a $\mathrm{C}$ horizon ranging four to five meters deep. This type of soil originates from sandy clay sediments, and is characterized by low natural fertility, good drainage, and high permeability. Mining resulted in an exposed $\mathrm{C}$ horizon after the removal of a 10-meter soil layer, affecting local drainage network, soil physical, chemical and biological properties, and local biodiversity as well. When the exploitation ended, the area became a landfill for the disposal of refuse piles. Local land reclamation included the removal of the refuse from soil surface, soil systematization, the management of stormwater runoff, and finally, the planting of seedlings of Mimosa caesalpiniifolia and M. bimucronata. There were no plants on the experimental area before seedling plantation. Table 1 shows data of soil fertility and texture prior to the experiment. These previous analyses were used as the baseline (reference) for the evaluation of treatment effects six years after planting, although they were not used in the statistical analysis.

\subsection{Study design and sampling}

In late January 2001 we began a study on the viability of recovering the mining area using both fast growing tree species (Mimosa caesalpiniifolia and Mimosa bimucronata) and sewage sludge produced by the airport wastewater treatment plant. A 2 x 5 factorial experiment (under randomized block condition) with four replications was designed. Treatments consisted of a combination of two tree species inoculated with efficient nitrogen-fixing bacterial strains and four sludge doses (0, 2.85; 5.70; 11.40 and 22.80 $\mathrm{Mg} \mathrm{ha}^{-1}$ ). The sludge chemical composition is shown in Table 2.

Mimosa seedlings were planted in $0.30 \times 0.30 \mathrm{x}$ $0.30 \mathrm{~m}$ holes, with a $2.0 \mathrm{~m}$ x $2.0 \mathrm{~m}$ spacingof planting. The total area of each plot was $64 \mathrm{~m}^{2}$ (16 plants treatment $\mathrm{t}^{-1}$ ). For seedling fertilization, 80 grams of rock phosphate and 30 grams of potassium phosphate were applied in each hole. Both fertilizer and sludge were mixed and incorporated to the hole when seedlings were planted. In June 2003 sludge application was repeated using the same dose of the first application. During the first half of 2007 a yard stick and a meansuring tape were used to measure the height and circumference at breast height $(\mathrm{CBH})$ of each tree of two of the four blocks. Both the diameter at breast height (DBH) and the basal area were calculated from the $\mathrm{CBH}$ data. Trees with the respective value closest to the mean value calculated were selected for cutting. Between July and August 2007, three trees from each treatment were cut in Block 1 and one individual from treatments 1 and 2 (control), 3 and 4 (mean dose), and 5 and 6 (maximum dose) in blocks 2 and 3, totaling 18 trees of each species. After the trees were cut, their parts (leaves, branches and trunks) were separated and weighed in the field for sampling. Since sampling was performed in the driest months, few leaves were found, and the identification of dead branches was difficult. All dead or living branches were then quantified without differing them. In the Soil, Water and Plant Analysis laboratory (LASP) of Embrapa Solos, they were dried at $65^{\circ} \mathrm{C}$ to determine their total dry weight. Subsamples were ground to determine the $\mathrm{C}$ content by dry digestion in a Perkin Elmer elemental analyzer (model 2400CHNS/O). As bark from trunk samples was ground separately, only the carbon stock $\left(\mathrm{Mg} \mathrm{ha}^{-1}\right)$ of the trunk and branches was estimated based on the dry biomass and $\mathrm{C}$ content values.

Revista Árvore. 2017;41(6):e410610 
Table 1-Chemical and physical attributes $(0-20 \mathrm{~cm})$ of substrate prior to the experiment (extracted from Bezerra et al., 2006).

Tabela 1 - Atributos químicos e físicos $(0-20 \mathrm{~cm})$ do substrato antes da implantação do experimento (extraído de Bezerra et al., 2006).

\begin{tabular}{|c|c|c|c|c|c|c|c|c|c|c|c|c|c|}
\hline \multirow{2}{*}{ Block } & Deph & $\mathrm{pH} \mathrm{H} \mathrm{H}_{2} \mathrm{O}$ & $\mathrm{C}$ & $\mathrm{N}$ & $\mathrm{Ca}$ & Mg & $\mathrm{Na}$ & $\mathrm{K}$ & $\mathrm{Al}$ & $\mathrm{P}$ & Clay & Sand & Silt \\
\hline & $\mathrm{cm}$ & $(1: 2,5)$ & $\mathrm{g} \mathrm{kg}^{-1}$ & \multicolumn{7}{|c|}{$\mathrm{mg} \mathrm{kg}^{-1}$} & \multicolumn{3}{|c|}{$\mathrm{g} \mathrm{kg}^{-1}$} \\
\hline 1 & $(0-10)$ & 7,2 & 1,7 & 0,4 & 701,4 & 130,3 & 25,3 & 46,9 & 0,0 & 0,3 & 260 & 499 & 241 \\
\hline 2 & $(0-10)$ & 7,3 & 2,1 & 0,2 & 641,3 & 90,2 & 29,9 & 54,7 & 0,0 & 1,1 & 280 & 547 & 173 \\
\hline 3 & $(0-10)$ & 7,9 & 2,9 & 1,3 & 641,3 & 90,2 & 11,5 & 37,2 & 0,0 & 3,0 & 220 & 590 & 190 \\
\hline
\end{tabular}

Table 2 - Chemical composition of sewage sludge used in the experiment (Bezerra et al., 2006).

Tabela 2 - Composição química do lodo de esgoto usado no experimento (Bezerra et al., 2006).

\begin{tabular}{cccccccccc}
\hline Moiture & $\mathrm{pH}\left(\mathrm{H}_{2} \mathrm{O}\right)$ & Organic C & TotalN & $\mathrm{C} / \mathrm{N}$ & $\mathrm{P}$ & $\mathrm{K}$ & $\mathrm{Mg}$ & $\mathrm{Ca}$ & $\mathrm{Na}$ \\
\hline $\mathrm{g} \mathrm{kg}^{-1}$ & $(1: 2,5)$ & $\mathrm{g} \mathrm{kg}^{-1}$ & $\mathrm{~g} \mathrm{~kg}^{-1}$ & & $\mathrm{mg} \mathrm{kg}$ & $\mathrm{mg} \mathrm{kg}^{-1}$ & $\mathrm{mg} \mathrm{kg}^{-1}$ & $\mathrm{mg} \mathrm{kg}^{-1}$ & $\mathrm{mg} \mathrm{kg}^{-1}$ \\
8.2 & 5.6 & 224.1 & 26.7 & 8.4 & 4,800 & 1,000 & 3,400 & 15,400 & 400 \\
\hline $\mathrm{Fe}$ & $\mathrm{Al}$ & $\mathrm{B}$ & $\mathrm{Mn}$ & $\mathrm{Cu}$ & $\mathrm{Zn}$ & $\mathrm{Ni}$ & $\mathrm{Cr}$ & $\mathrm{Pb}$ & $\mathrm{Cd}$ \\
\hline $\mathrm{mg} \mathrm{kg}^{-1}$ & $\mathrm{mg} \mathrm{kg}^{-1}$ & $\mathrm{mg} \mathrm{kg}^{-1}$ & $\mathrm{mg} \mathrm{kg}^{-1}$ & $\mathrm{mg} \mathrm{kg}^{-1}$ & $\mathrm{mg} \mathrm{kg}^{-1}$ & $\mathrm{mg} \mathrm{kg}^{-1}$ & $\mathrm{mg} \mathrm{kg}^{-1}$ & $\mathrm{mg} \mathrm{kg}^{-1}$ & $\mathrm{mg} \mathrm{kg}^{-1}$ \\
19,200 & 13,100 & 70 & 200 & 362.7 & $1,543.3$ & 39.2 & 72.7 & 185.3 & 3.1 \\
\hline
\end{tabular}

In July 2007, litterfall was completely removed from soil surface, the recovered substrate was sampled in three small trenches per plot that had been dug with a mattock. Samples were carefully collected to represent the treatment adequately and later were sent for chemical characterization after being dried and sieved. Exchangeable nutrients: $\mathrm{Ca}^{2+} \mathrm{Mg}^{2+}$ and $\mathrm{Al}^{3+}$ extracted by $1 \mathrm{M} \mathrm{KCl}$; P and K by Mehlich-1 extractant (0.05 mol L-1 in $\mathrm{HCl}$ in $0.0125 \mathrm{~mol} \mathrm{~L}^{-1} \mathrm{H}_{2} \mathrm{SO}_{4}$ ) and $\mathrm{pH}$ (soil:water 1:5); potential acidity: $\mathrm{H}+\mathrm{Al}$ extracted with calcium acetate $1 \mathrm{~N}$ (pH 7), titrated with $0.0125 \mathrm{~N} \mathrm{NaOH}$, were analyzed according to Empresa Brasileira de Pesquisa Agropecuária (1997). Inductively coupled plasma (ICP) apparatus for $\mathrm{Ca}^{2+} \mathbf{M g}^{2+}$ and $\mathrm{Al}^{3+}$, flame emission for $\mathrm{K}$ and photocolometry for $\mathrm{P}$ were used for nutrient determination. The sum of bases cations (S) (Ca, Mg and K), effective cation exchange capacity ( $\mathrm{T})$, calculated as the sum of $\mathrm{S}+(\mathrm{H}+\mathrm{Al})$ and the base saturation $(\mathrm{S} / \mathrm{T})$, also were calculated. After these soils were sampled, new samples $(0-10 \mathrm{~cm})$ were also collected with a $100 \mathrm{~cm}^{3}$ Koppeck ring to determine soil density. Carbon stocks were calculated using the following equation:

$$
E=(C \times \rho \times E) / 10 \text {, }
$$

where $\mathrm{E}=$ soil $\mathrm{C}$ stock $\left.\mathrm{Mg} \mathrm{ha}^{-1}\right)$; $\mathrm{C}=$ soil $\mathrm{C}$ content $\left(\mathrm{g} \mathrm{kg}^{-1}\right) ; \rho=$ bulk density $\left(\mathrm{g} \mathrm{cm}^{-3}\right)$; and $\mathrm{E}=$ soil layer thickness $(\mathrm{cm})$. No correction for soil mass was made to calculate the stocks.

\subsection{Statistical analysis}

The effects of species and sludge doses, as well as the interaction of these factors, were tested using analysis of variance at a $5 \%$ level of probability. When dose factor significance was detected, regression adjustment was done to describe better the effects of doses. Data from the $11.40 \mathrm{Mg} \mathrm{ha}^{-1}$ sludge dose were not used in the statistical analysis, as plant growth values at this dose did not match the trend observed in the other doses, which may suggest a possible error in the application of sewage sludge.

\section{RESULTS}

Legume species performance were found to be different for height $(\mathrm{p}<0.01)$ and basal area $(\mathrm{p}<0.05)$ values, but no effect of sludge levels was detected on those variables for either species (Figure 1). M. caesalpiniifolia presented the highest height values for all sludge doses, with mean values of $7.6 \mathrm{~m}$. M. bimucronata presented a mean height of $6.1 \mathrm{~m}$.

Both biomass and $\mathrm{C}$ stock accumulated in the trunks and branches were found to be different between Mimosa caesalpiniifolia and Mimosa bimucronata $(\mathrm{p}<0.05)$ (Table 3). However, the effect of sludge doses was detected only for their trunks. No significant interaction was found between sludge doses and species. M. caesalpiniifolia had higher dry biomass for both branch and trunk (average values of 30.3 and $58.4 \mathrm{Mg} \mathrm{ha}^{-1}$, respectively) than $M$. bimucronata (20.8 and $31.8 \mathrm{Mg} \mathrm{ha}^{-1}$ ) regardless of the

Revista Árvore. 2017;41(6):e410610 


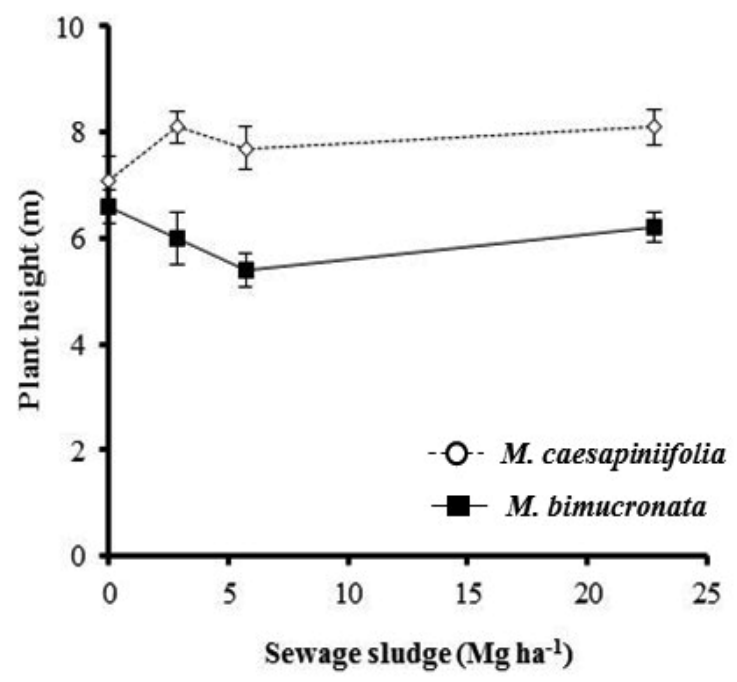

(b)

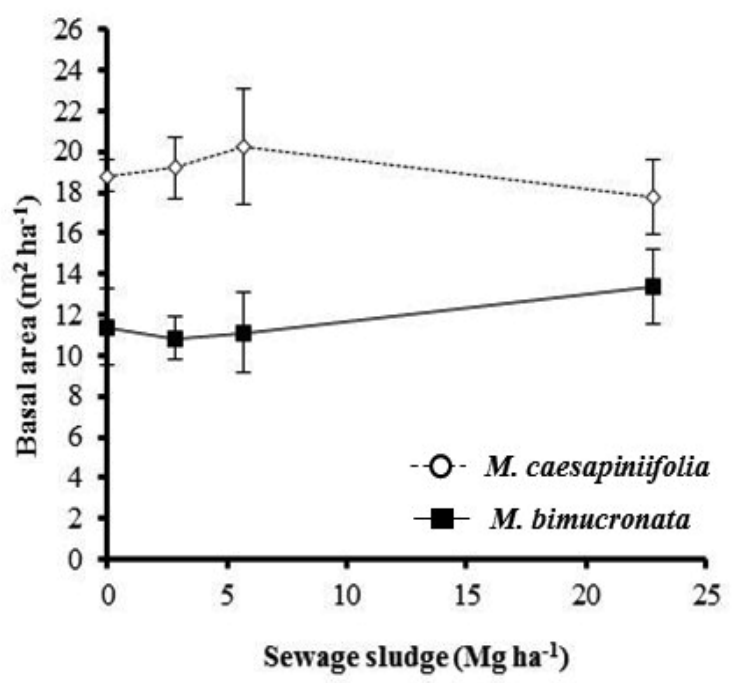

Figure 1 - Height (m) and basal area $\left(\mathrm{m}^{2} \mathrm{ha}^{-1}\right)$ of Mimosa caesalpiniifolia Benth and Mimosa bimucronata (DC.) O. Kuntze, submitted to different sewage sludge doses six years after tree transplantion. Mean \pm standard deviation

Figura 1 - Altura $(\mathrm{m})$ e área basal $\left(\mathrm{m}^{2} \mathrm{ha}^{-1}\right)$ de Mimosa caesalpiniifolia Benth e Mimosa bimucronata (DC.) $O$. Kuntze, submetidos a diferentes doses de lodo de esgoto, aos 6 anos após transplantio. Média \pm desvio-padrão. amount of sludge supplied. Biomass production accounted for species above-ground C stock (M. caesalpiniifolia trunk, 27.3 $\mathrm{Mg} \mathrm{ha}^{-1}$; $M$. bimucronata trunk, 14.7 $\mathrm{Mg} \mathrm{ha}^{-1} ; M$. caesalpiniifolia branches, $14.1 \mathrm{Mg} \mathrm{ha}^{-1}$ and $M$. bimucronata branches, $9.9 \mathrm{Mg} \mathrm{ha}^{-1}$ ). C concentration mean values used to estimate $\mathrm{C}$ stocks for trunk and branches were very close (M. Caesalpiniifolia, $46.8 \pm 0.4 \mathrm{~g} \mathrm{~kg}^{-1}$, and 46.4 $\pm 0.4 \mathrm{~g} \mathrm{~kg}^{-1}$; M. bimucronata branches: $46.3 \pm 0.6$ and $\left.47.7 \pm 0.4 \mathrm{~g} \mathrm{~kg}^{-1}\right)$.

No significant differences were observed in the soil density due to the sludge dose. Similarly, the C stocks in the superficial soil layer $(0-10 \mathrm{~cm})$ did not differ between the Mimosa caesalpiniifolia and Mimosa bimucronata plots or for the sludge doses. Six years after planting, the soil $\mathrm{C}$ stocks reached average values of 12.0 and $12.2 \mathrm{Mg} \mathrm{ha}^{-1}$ for $M$. caesalpinifolia and $M$. bimucronata, respectively.

The application of different sludge doses did not significantly alter the chemical attributes associated to fertility (Table 4). On the other hand, legume trees themselves improve the substrate quality, as the nutritional status of the substrate improves in comparison to its quality before legume planting.

\section{DISCUSSION}

The Fabaceae is a huge family considered the third largest land plant family. It is the most common family found in tropical rainforests and in dry forests in the Americas and Africa (Burnham and Johnson, 2004). With a widespread distribution across the word and in Brazil, sometimes the introduction of nitrogen fixing tree representatives could not be imply in successful restoration practices. So, we attributed the behavior of $M$. caesalpiniifolia and $M$. bimucronata studied to their origin, since the first is a native species of the Caatinga biome (a harsh environment for plant growth) and $M$. bimucronata is a native species of subtropical regions. As Rio de Janeiro has a hot and humid climate, M. caesalpiniifolia found a better environment to grow, confirming what Bezerra et al. (2006) found when evaluated the experiment 210 days after planting.

The performance of $M$. caesalpiniifolia in postmining soils can be considered satisfactory (41.4 Mg ha $^{-1}$ after 6 years), since the rates of aboveground dry matter accumulation ( $\mathrm{Mg} \mathrm{ha}^{-1}$ year $^{-1}$ ) were slightly higher than those reported by Baggio and Carpanezzi (1997) in Curitiba, Paraná (South region) and Moura et al. (2006) in Itambé, in the state of Pernambuco (Northeast

Revista Árvore. 2017;41(6):e410610 
Table 3 - Dry biomass (Mg.ha-1) of branches and trunks and respective C stocks (Mg.ha' ${ }^{-1}$, in parenthesis) of Mimosa caesalpiniifolia Benth and Mimosa bimucronata (DC.) O. Kuntze, submitted to different sewage sludge doses.

Tabela 3 - Matéria seca da parte aérea $\left(\mathrm{Mg}_{\mathrm{h}} \mathrm{ha}^{-1}\right)$ de galhos e troncos e respectivos estoques (entre parênteses, $\mathrm{Mg}_{\mathrm{g}} \mathrm{ha^{-1 }}$ ) de Mimosa caesalpiniifolia Benth e Mimosa bimucronata (DC.) O. Kuntze, submetidas a diferentes doses de lodo de esgoto.

\begin{tabular}{cccc}
\hline $\begin{array}{c}\text { Sewage sludge doses } \\
\text { Mg ha }^{-1}\end{array}$ & Branches & Trunk & Total \\
\cline { 2 - 4 } 0 & & Mimosa caesalpinifolia & \\
0 & $31.30 \pm 14.86^{\mathrm{a}}(14.52)$ & $43.67 \pm 4.27(20.44)$ & $74.97(34.96)$ \\
2.85 & $30.30 \pm 9.32(14.06)$ & $65.45 \pm 8.18(30.63)$ & $95.75(44.69)$ \\
5.70 & $29.16 \pm 11.55(13.53)$ & $59.48 \pm 8.41(27.83)$ & $88.63(41.36)$ \\
22.80 & $30.29 \pm 7.54(14.05)$ & $64.85 \pm 11.54(30.35)$ & $95.14(44.40)$ \\
\hline Average & $30.26(14.05) \mathrm{A}$ & $58.36(27.31) \mathrm{A}$ & \\
\hline & & Mimosa bimucronata & \\
0 & $12.01 \pm 8.2(5.73)$ & $25.07 \pm 11.52(11.61)$ & $37.08(17.34)$ \\
2.85 & $18.41 \pm 1.64(8.79)$ & $21.30 \pm 6.14(9.87)$ & $39.71(18.65)$ \\
5.70 & $23.06 \pm 10.33(11.00)$ & $41.04 \pm 22.04(19.01)$ & $64.10(30.01)$ \\
22.80 & $29.92 \pm 14.63(14.28)$ & $39.64 \pm 19.04(18.36)$ & $69.55(32.64)$ \\
\hline Average & $20.85(9.95) \mathrm{A}$ & $31.76(14.71) \mathrm{B}$ & $52.61(24.66) \mathrm{B}$ \\
\hline
\end{tabular}

a. Mean \pm standard deviation * Mean value followed different letter, in the same column, show significant difference in the Tukey test (5\% probability);

Table 4 - Substrate fertility $(0-10 \mathrm{~cm})$ at the end of the experiment. Mean values \pm standard deviation (in parentheses) Tabela 4 - Fertilidade do substrato $(0-10 \mathrm{~cm})$ ao final do experimento.Valores médios dos atributos \pm desvio-padrão (entre parênteses)

\begin{tabular}{|c|c|c|c|c|c|c|c|c|c|c|c|c|}
\hline \multirow[t]{2}{*}{ Doses } & \multirow[t]{2}{*}{ Species } & $\mathrm{pH} \mathrm{H}_{2} \mathrm{O}^{\mathrm{a}}$ & $\mathrm{Al}^{\mathrm{b}}$ & $\mathrm{Ca}^{\mathrm{b}}$ & $\mathrm{Mg}^{\mathrm{b}}$ & $\mathrm{K}^{\mathrm{c}}$ & $\mathrm{H}+\mathrm{Al}^{\mathrm{d}}$ & $\mathrm{P}^{\mathrm{c}}$ & $\mathrm{S}^{\mathrm{e}}$ & $T^{f}$ & $V^{5}$ & $\mathrm{C}^{\mathrm{h}}$ \\
\hline & & $(1: 2.5)$ & $-\mathrm{cm}$ & $1^{-3}-$ & & & $\mathrm{cmol}_{\mathrm{c}} \cdot \mathrm{dm}^{-3}$ & mg. dm ${ }^{-3}$ & $\mathrm{cmol}_{\mathrm{c}} \mathrm{dm}^{-3}$ & & $\%$ & $\mathrm{~g} / \mathrm{kg}$ \\
\hline
\end{tabular}

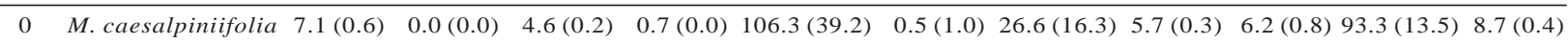

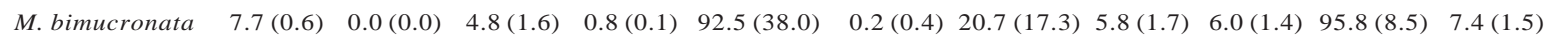

2.85 M. caesalpiniifolia $7.6(0.6) \quad 0.0(0.0) \quad 4.6(1.6) \quad 0.8(0.2) \quad 107.3(28.0) \quad 0.0(0.0) \quad 15.1(11.0) \quad 5.7(1.6) \quad 5.7(1.6) \quad 100.0(0.0) \quad 7.7(1.8)$

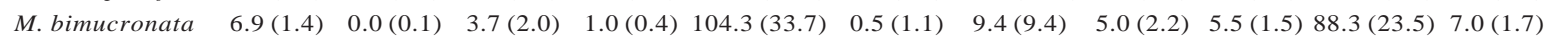

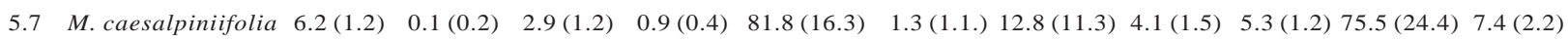

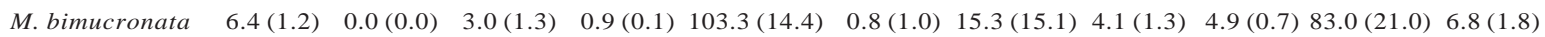
22.8 M. caesalpiniifolia $7.2(0.7) \quad 0.0(0.0) \quad 4.5(2.0) \quad 0.9(0.5) \quad 95.5(16.9) \quad 0.3(0.7) \quad 12.3(5.2) \quad 5.7(2.5) \quad 6.1(2.2) 93.5(13.0) \quad 6.0(2.3)$ \begin{tabular}{lllllllllllll} 
M. bimucronata & $7.4(0.5)$ & $0.0(0.0)$ & $4.1(0.6)$ & $0.8(0.3)$ & $93.8(56.0)$ & $0.2(0.4)$ & $27.1(17.4)$ & $5.2(0.3)$ & $5.4(0.5)$ & $96.5(7.0)$ & $8.2(3.1)$ \\
\hline
\end{tabular}

a. $\mathrm{pH}$ (soil:water, 1:5); ${ }^{\text {b. }}$ Exchangeable nutrients: $\mathrm{Ca}^{2+} \mathrm{Mg}^{2+}$ and $\mathrm{Al}^{3+}$ extracted by $1 \mathrm{M} \mathrm{KCl}$; ${ }^{\text {c. }} \mathrm{P}$ and $\mathrm{K}$ by Mehlich-1 extractant $(0.05$ mol L-1 in $\mathrm{HCl}$ in $0,0125 \mathrm{~mol} \mathrm{~L}^{-1} \mathrm{H}_{2} \mathrm{SO}_{4}$ ); d. potential acidity: $\mathrm{H}+\mathrm{Al}$ extracted with calcium acetate $1 \mathrm{~N}(\mathrm{pH} 7)$, titrated with 0.0125

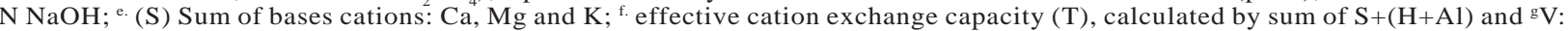
base saturation (S/T)x100)); ${ }^{\text {h }} \mathrm{C}$ : total organic carbon (dry combustion)

region), in undisturbed areas. On the other hand, $M$. bimucronata showed a worse performance in the present study (24.6 $\mathrm{Mg} \mathrm{ha}^{-1}$ ) than others reported by Fortes (2000), who evaluated several native and exotic species (Acacia mangium, Mimosa caesalpiniifolia ( $M$. caesalpinifolia), Mimosa acutistipula, Prosopis juliflora, Leucaena leucocephala) under bauxite mine soil mixed with alkaline ash exposure.

A high spatial variability of soil attributes was responsible for the lack of statistic difference among the treatments and this was corroborated by Banning et al. (2008) and Nyamadzawo et al. (2008). According to Nyamadzawo et al. (2008) on minesoils and unmined sites there is an increase in sample variance over increasing amount of time, especially for some soil properties. The coefficient of variation (CV) for bulk density was lower, $<15 \%$ percent at each site and depth, while for total C concentration and stocks, CV was high, 35 percent across all mined soils, and generally increased with depth.

Despite the differences in growth and carbon aboveground accumulation, no differences were found between species and sludge doses for soil carbon stocks. In addition, the values found ( $\left.12 \mathrm{Mg} \mathrm{ha}^{-1}\right)$ were lower

Revista Árvore. 2017;41(6):e410610 
than those reported by Macedo et al. (2008) in sites reclaimed by planting legume trees (21.5 $\mathrm{Mg} \mathrm{ha}^{-1}$ ). Nevertheless, differences in plantation ages (six years for the Itacolomi site vs. 13 for the Angra dos Reis area), in the number of species planted, and even in the local site resilience in Angra dos Reis due to the close proximity to a significant Atlantic Forest remnant (Ribeiro et al., 2009), that improve the sucessional process could also justify these differences. The higher presence of grasses under the sites studied by Macedo et al. (2008) in comparison with our work corroborates the results of Silva et al. (2013) who observed a synergistic unprecedented carbon accumulation in an opencast mine area effects of resources input (biosolid: tertiarytreatment domestic sewage sludge) and plant species invasion of grasses under 14-year restoration chronosequence (Silva et al., 2013). Bendfeldt et al. (2001) discuss that it is reasonable that a new pattern of aboveground and belowground interactions may resulted in $\mathrm{C}$ accumulation in degraded substrates. These authors reported that 16 years after applying different soil conditioners (topsoil, sawdust, municipal sewage sludge - 22, 56, 112 and $224 \mathrm{Mg} \mathrm{ha}^{-1}$ ), C stocks had accumulated up to $8-10 \mathrm{Mg} \mathrm{ha}^{-1}$ in $1 \mathrm{~m}$-deep base layer of 2:1 sandstone to siltstone overburden material, for all treatments.

Using the C stocks (3.5 Mg ha-1) from 2001 (year of experiment installation) as baseline ( $\mathrm{C}$ data from Bezerra et al., 2006 and bulk density from our work), the rate of $\mathrm{C}$ sequestration for the first 6 years of reclaimed mine was estimated at $1.44 \mathrm{Mg} \mathrm{ha}^{-1}$ year $^{-1}$, a figure that corroborates several authors (Wick et al., 2013: 1.272.00 $\mathrm{Mg} \mathrm{ha}^{-1}$ year $^{-1}$; Shrestha and Lal, 2006: 0.7-4.0 Mg ha $^{-1}$ year-1; Macedo et al., 2008: 1.73 $\mathrm{Mg} \mathrm{ha}^{-1}$ year-1) $^{-1}$ for different reclaimed soils.

As observed in carbon stocks, different sludge doses did not change chemical attributes significantly after six years of planting. Although there were no significant interspecies differences, a lowered $\mathrm{pH}$ substrate detected after 180 days of planting the legume species (Bezerra et al., 2006) was still observed — slightly higher for M. caesalpiniifolia. Despite the local applications, the sludge doses caused significant $\mathrm{pH}$ alterations and the regression models tested for each species did not allow good adjustments. Even though the literature widely states that atmospheric $\mathrm{N}_{2}$ fixing legume species can reduce soil pH (Raven et al., 1990; Wang et al., 2010), other factors, such as litterfall decomposition, soil respiration, cations uptake by legumes, or their spread by leaching, as well as the influence of atmospheric deposition, can favor soil $\mathrm{pH}$ reduction (Binkley and Giardina, 1997; Yamashita et al., 2008).

On the other hand, the average Ca and Mg content (all doses) in soil under both $M$. caesalpinifolia (4.14 and $0.83 \mathrm{cmol}_{\mathrm{c}} \mathrm{dm}^{-3}$ ) and $M$. bimucronata (3.88 and $0.83 \mathrm{cmolc} \mathrm{dm}^{-3}$ ) were found to be higher six years after planting. Considering that the sludge levels had no effects when applied in the planting holes, it could suggest that fertilization itself plus plant growth were enough to trigger local biogeochemical cycling.

A great improvement in K levels in the superficial soil layer sampled was observed, with levels approximately $50 \%$ higher than those detected by Bezerra et al. (2006). Considering that the K content was high before planting, and the high mobility of this nutrient in plants, it can be inferred that it was intensely and efficiently recycled during the study period. As cited before, the natural seasonal fall of leaves may have accounted for a great biomass accumulation on soil surface. Phosphorus was the only soil attribute that was significantly affected by the sludge doses, even though the regression models tested for each species did not allow good adjustments. This result could be explained by the fact that organic and humic substances in the sludge may have increased phosphate uptake by the plants, given that they can block phosphate adsorption sites of oxides and hydroxides of Fe and $\mathrm{Al}$ from the substrate - not only at the hole level but also for plot level (Sibanda and Young, 1986; Hua et al., 2008; Rocha et al., 2015). The increase in $\mathrm{C}$ concentration and stocks appears to modulate the phosphorus dynamic in this degraded area. Efforts in terms of studies are recommended in this direction as $\mathrm{C}$ (and N) contents in soils could increase in detriment of $\mathrm{P}$ availability, depending on the mixture and structure of the forest planted (Kaye et al., 2000; Koutika et al., 2014).

After six years the successive process of planting had begun, the species Pannicum maximum (Colonião grass) and some Leucaena leucocephla (leucena) plants were dispersed in all plots. The grass was dominated by the trees planted, while leucaena reached the same size as them. With low representatives in terms of number and biomass, we believed that the contribution of both species for soil C stocks estimations was also low, as well as their contribution for the aboveground biomass.

Revista Árvore. 2017;41(6):e410610 


\section{CONCLUSION}

The $M$. caesalpiniifolia was found to grow better in reclaimed areas than $M$. bimucronata, even though neither the height nor the basal area of either species responded to the sludge levels tested. On other hand the carbon stocked in the tree trunks was affected by the doses of sewer sludge applied, whereas the soil carbon stock was not. The degraded substrate fertility was improved by the revegetation strategy, although no significant differences were observed between the treatments after six years for any attribute, except phosphorus availability, which was affected by sludge levels. Finally, we concluded reclaimed areas revegetated with leguminous trees can stock significant amounts of $\mathrm{C}$, in both aboveground biomass and soil, in a short course of time.

\section{REFERENCES}

Baggio AJ, Carpanezzi AA. Biomassa aéreada bracatinga Mimosa scabrella Benth. em talhões do sistema de cultivo tradicional. Bol Pesqui Florest. 1997;34:31-441.

Balieiro FC, Pereira MG, Alves BJR, Resende AS, Franco AA. Soil carbon and nitrogen in afforested pasture with eucalyptus and guachapele. Rev Bras Ciênc Solo. 2008;32(3):1253-60. http:// dx.doi.org/10.1590/S0100-06832008000300033.

Banning NC, Grant CD, Jones DL, Murphy DV. Recovery of soil organic matter, organic matter turnover and nitrogen cycling in a post-mining rehabilitation chronosequence. Soil Biol Biochem. 2008;40(8):2021-31. http://dx.doi.org/10.1016/ j.soilbio.2008.04.010.

Bendfeldt ES, Burger JA, Daniels L. Quality of amended mine soils after sixteen years. Soil Sci Soc Am J. 2001;65(6):1736-44. http://dx.doi.org/ 10.2136/sssaj2001.1736.

Bengtsson J, Angelstam P, Elmqvist T, Emanuelsson U, Folke C, Ihse M, et al. Reserves, resilience and dynamic landscape. Ambio. 2003;32(6):389-96. http://dx.doi.org/10.1579/00447447-32.6.389. PMid:14627367.

Bezerra FB, Oliveira MACL, Perez DV, Andrade AG, Meneguelli NA. Lodo de esgoto em revegetação de área degradada. Pesqui Agropecu
Bras. 2006;41(3):469-76. http://dx.doi.org/10.1590/ S0100-204X2006000300014.

Binkley D, Giardina C. Nitrogen fixation in tropical forest plantations. In: Nambiar EKS, Brown AG. Management of soil, nutrients and water in tropical plantation forests. Camberra: ACIAR; 1997. p. 297337

Burnham RJ, Johnson KR. South American palaeobotany and the origins of neotropical rain forests. Phil. Trans. Roy. Soc. 2004;359(1450):1595610. http://dx.doi.org/10.1098/rstb.2004.1531. PMid:15519975.

Camargo JLC, Ferraz IDK, Imakawa AM. Rehabilitation of degraded áreas of central Amazonia using direct sowing of forest tree seeds. Restor Ecol. 2002;10(4):636-44. http://dx.doi.org/ 10.1046/j.1526-100X.2002.01044.x.

Chaer GM, Resende AS, Campello EFC, Faria SM, Boddey RM. Nitrogen-fixing legume tree species for the reclamation of severely degraded lands in Brazil. Tree Physiol. 2011;31(2):139-49. http:// dx.doi.org/10.1093/treephys/tpq116. PMid:21378065.

Chaudhuri S, Mcdonald LM, Pena-Yewtukhiw EM, Skousen J, Roy M. Chemical stabilized soil organic carbono fractions in reclaimed minesoil chornosequence: implications for soil carbon sequestration. Environ Earth Sci. 2013;70(4):168998. http://dx.doi.org/10.1007/s12665-013-2256-8.

Empresa Brasileira de Pesquisa Agropecuária. Manual de métodos de análise de solo. Rio de Janeiro: EMBRAPA/SNLCS; 1997.

Evans DM, Zipper CE, Burger JA, Strahm BD, Villamagna AM. Reforestation practice for enhancement of ecosystem services on a compacted surface mine: path toward ecosystem recovery. Ecol Eng. 2013;51:16-23. http://dx.doi.org/ 10.1016/j.ecoleng.2012.12.065.

Fortes JLO. Reabilitação de depósito de rejeito do refino de bauxita com o uso de resíduos industriais e leguminosas arbóreas [tese]. Seropédica: Universidade Federal Rural do Rio de Janeiro; 2000.

Franco AA, Faria SM. The contribution of $\mathrm{N}_{2}-$ fixing tree legumes to land reclamation and

Revista Árvore. 2017;41(6):e410610 
sustainability in the tropics. Soil Biol Biochem. 1997;29(5-6):897-903. http://dx.doi.org/10.1016/ S0038-0717(96)00229-5.

Hua Q-X, Li J-Y, Zhou J-M, Wang H-Y, Du C-W, Chen X-Q. Enhancement of phosphorus solubility by humic substance in Ferrasols. Pedosphere. 2008;18:33-538. http://dx.doi.org/10.1016/S10020160(08)60044-2.

Kanowski J, Catterall CP. Carbon stocks in aboveground biomass of monoculture plantations, mixed species plantations and environmental restoration plantings in north-east Australia. Ecol Man Rest. 2010;11(2):119-26. http://dx.doi.org/10.1111/j.14428903.2010.00529.x.

Kaye JP, Resh SC, Kaye MW, Chimner RA. Nutrient and carbon dynamics in a replacement series of Eucalyptus and Albizia trees. Ecology. 2000;81(12):3267-73. http://dx.doi.org/10.1890/00129658(2000)081[3267:NACDIA]2.0.CO;2.

Koutika LS, Epron D, Bouillet JP, Mareschal L. Changes in $\mathrm{N}$ and $\mathrm{C}$ concentration, soil acidity and $\mathrm{P}$ availability in tropical mixed acacia and eucalyptus plantations on a nutrient-poor sandy soil. Plant Soil. 2014;379(1-2):205-16. http:// dx.doi.org/10.1007/s11104-014-2047-3.

Macedo MO, Resende AS, Garcia PC, Boddey RM, Jantalia CP, Urquiaga S, et al. Changes in soil $\mathrm{C}$ and $\mathrm{N}$ stocks and nutrient dynamics 13 years after recovery of degraded land using leguminous nitrogen-fixing trees. For Ecol Manage. 2008;255(5-6):1516-24. http://dx.doi.org/10.1016/ j.foreco.2007.11.007.

Moura ON, Passos MAA, Ferreira RLC, Molica SG, Lira MA Jr, Lira MA, et al. Distribuição de biomassa e nutrientes na aréa de Mimosa caesalpiniaefolia Benth. Rev Arvore. 2006;30(6):877-84. http://dx.doi.org/10.1590/S010067622006000600002 .

Nyamadzawo G, Shukla MK, Lal R. Spatial variability of total soil carbon and nitrogen stocks for some reclaimed minesoils of Southeastern Ohio. Land Degrad Dev. 2008;19(3):275-88. http:// dx.doi.org/10.1002/ldr.841.

Parrotta JA, Knowles OH. Restoration of tropical moist forest on bauxite-mined lands in the
Brazilian Amazon. Restor Ecol. 1999;7(2):103-16. http://dx.doi.org/10.1046/j.1526-100X.1999.72001.x.

Parrotta JA, Knowles OH. Restoring tropical forests on lands mined for bauxite: examples from the Brazilian Amazon. Ecol Eng. 2001;17(2-3):219-239. http://dx.doi.org/10.1016/S0925-8574(00)00141-5.

Raven JA, Franco AA, Jesus EL, Jacob-Neto J. H+ extrusion and organic-acid synthesis in $\mathrm{N}_{2}$-fixing symbioses involving vascular plants. New Phytol. 1990;114(3):369-89. http://dx.doi.org/10.1111/j.14698137.1990.tb00405.x.

Reis LL. Monitoramento da recuperação ambiental de áreas de mineração de bauxita na Floresta Nacional de Saracá-Taquera, Porto Trombetas (PA) [tese]. Seropédica: Universidade Federal Rural do Rio de Janeiro; 2006.

Resende AS, Macedo MO, Campello EF, Franco AA. Recuperação de áreas degradadas através da reengenharia ecológica. In: Garay I, Becker BK, editores. Dimensões humanas da biodiversidade. 1. ed. Petropólis: Vozes; 2006. p. 315-340. Vol. 1.

Ribeiro MC, Metzger JP, Martensen AC, Ponzoni FJ, Hirota MM. The Brazilian Atlantic Forest: how much is left, and how is the remaining forest distributed? Implications for conservation. Biol Conserv. 2009;142(6):1141-53. http://dx.doi.org/ 10.1016/j.biocon.2009.02.021.

Rocha JHI, Santos AJM, Diogo FA, Backes C, Melo AGC, Borelli K, et al. Reflorestamento e recuperação de atributos químicos e físicos do solo. Floresta Ambient. 2015;22(3):299-306. http:// dx.doi.org/10.1590/2179-8087.041613.

Rodrigues RR, Lima RAF, Gandolfi S, Nave AG. On the restoration of high diversity forests: 30 years of experience in the Brazilian Atlantic Forest. Biol Conserv. 2009;142(6):1242-51. http:// dx.doi.org/10.1016/j.biocon.2008.12.008.

Shrestha RK, Lal R. Ecosystem carbon budgeting and soil carbon sequestration in reclaimed mined soil. Environ Int. 2006;32(6):781-96. http:// dx.doi.org/10.1016/j.envint.2006.05.001. PMid:16797072.

Sibanda HM, Young SD. Competitive adsorption of humic acids and phosphate on goethite, 
gibbsite and two tropical soils. Eur J Soil Sci. 1986;37(2):197-204. http://dx.doi.org/10.1111/j.13652389.1986.tb00020.x.

Silva LCR, Correa RS, Doane TA, Pereira EIP, Horwath WR. Unprecedented carbon accumulation in mined soils: the synergistic effect of resource input and plant species invasion. Ecol Appl. 2013;23(6):1345-56. http://dx.doi.org/10.1890/121957.1. PMid:24147407.

Singh AN, Zeng DH, Chen FS. Effect of young woody plantations on carbon and nutrient accretion rates in a redevelopment soil on coalmine spoil in a dry tropical environment, India. Land Degrad Dev. 2006;17(1):13-21. http:// dx.doi.org/10.1002/ldr.690.

Wang F, Li Z, Xia AH, Zou B, Li N, Liu J, et al. Effects of nitrogen-fixing and non-nitrogen-fixing tree species on soil properties and nitrogen transformation during Forest restoration in southern China. Soil Sci Plant Nutr.
2010;56(2):297-306. http://dx.doi.org/10.1111/ j.1747-0765.2010.00454.x.

Wick AF, Daniels WL, Orndorff ZW, Alley MM. Organic matter accumulation post-mineral sands mining. Soil Use Manage. 2013 Sep;29(3):354-3642013. http://dx.doi.org/ 10.1111/sum.12058.

Yamashita N, Ohta SS, Hardjono AA. Soil changes induced by Acacia mangium plantation establishment: Comparison with secondary forest and Imperata cylindrical grassland soils in South Sumatra, Indonesia. For Ecol Manage. 2008;254(2):362-70. http://dx.doi.org/10.1016/ j.foreco.2007.08.012.

Yang L, Liu N, Ren H, Wang J. Facilitation by two exotic Acacia: Acacia auriculiformis and Acacia mangium as nurse plants in South China. For Ecol Manage. 2009;257(8):1786-93. http://dx.doi.org/10.1016/j.foreco.2009.01.033. 